at five points, though not in situ, in the Glastonbury Lake Village. From the range of finds in the area of excavation of the present season, it is evident that this quarter of the village was a centre for weaving. Weaving combs, bobbings, needles of bone and no less than twenty-four spindle whorls were found. Among other objects were an iron dagger with bronze fittings, bronze finger rings, yellow paste beads, three spurs of fighting cocks, linked bronze wire and two 'cheek-pieces' of horses' bridle bits. Among the finds from the excavations of this and previous seasons, to be exhibited in the new Wyndham Galleries of the Somerset County Museum at Taunton, is a mounted set of the spikelets and grains of Triticum dicoccum found at Meare, with a set of its modern counterpart by its side. These have been prepared by Sir Rowland Biffen.

\section{Spanish Influence on Progress of Medicine}

ON the occasion of the International Congress of the History of Medicine, to be held at Madrid on September 23-29, the Wellcome Research Institution has issued a booklet illustrating Spain's contribution to medical science from the earliest times down to the discovery of cinchona in the seventeenth century. After alluding to Spanish contacts with former civilisations such as those of the Phonicians, Carthaginians, Greeks, Romans and Visigoths, the work deals with the Hispano-Moresque Renaissance, which was remarkable for the foundation of schools of medicine and pharmacy and the establishment of hospitals, some of which were equipped with large libraries, as well as for the appearance of eminent medical men, including Albucasis, the author of a great medico-chirurgical treatise which remained the leading textbook until the time of William of Saliceto (1275), Avenzoar, the greatest of the Hispano-Moresque physicians, and Maimonides, the Hispano-Jewish philosopher and physician, the octocentenary of whose birth has recently been celebrated. During the sixteenth and seventeenth centuries a large number of hospitals were founded in different parts of Spain, especially at Barcelona, Granada, Malaga and Madrid. The outstanding medical personalities of the sixteenth century in Spain were Nicolás Monardes, of Seville, whose private museum of natural objects was one of the earliest, if not the first, in Spain ; Francisco Hernandez, physician to Philip II and author of a monumental work on the natural history of Mexico; and Andres Laguna, physician to Charles V and Pope Julian III and professor at the University of Alcalá de Henares, where Cardinal Ximenes the founder had endowed six professorships of medicine and two of anatomy and surgery. The booklet is illustrated by facsimiles of pages from Spanish medical works, portraits of Spanish doctors and views of the old hospitals.

\section{Snake Bite in the United States of America}

Is 1908, Prentiss Willson gathered reports of 740 bites by poisonous snakes covering a period of almost a century. That result gave an entirely false idea of the prevalence of snake-bite in the United States, for Dr. T. S. Githens now records 2,376 cases which have come to his notice during the past eight years, and estimates that there may be 1,500-2,000 cases each year (Scientific Monthly, August 1935, p. 163). It may be, also, that the number of snakes is increasing, for when wilderness is converted into farm land, small rodents increase greatly in number, and these form the mainstay of the snakes' diet. The danger to health varies most with the amount of venom injected, and this is closely related to the size of the snake involved, so that the most dangerous species are the large Florida and Texan diamondbacks. The only local measure having any real value is the application of a moderately tight tourniquet, associated with free incision of the site of the bite and the swollen area and persistent use of suction. But the mainstay of treatment is the use of adequate doses of antivenum, a specific serum effective against the bites of North American vipers, which has reduced the mortality rate from $14 \cdot 3$ to $3 \cdot 7$ per cent. Of the 72 persons who died in spite of serum treatment, 25 were near death when the serum was first given, and in 6 other cases death was due to gangrene resulting from too tight tourniquets ; more than half were children less than fourteen years of age.

\section{The Voyage of Peter Mundy}

IN the Proceedings of the Linnean Society of London, Session 1934-35, Part 2, Mr. N. B. Kinnear and Mr. F. C. Fraser direct attention to the remarkable journals and zoological notes from the voyage of Peter Mundy, 1855-56. Some very clever sketches are reproduced showing a remarkable vivacity, and his notes show that he was a careful observer. Three volumes of his travels have already been published by the Hakluyt Society; the fourth and final volume is being edited by Miss Anstey, who assisted the late Sir Richard Temple with the earlier volumes. The running bird from Ascension Island illustrated which "can neither fly nor swimme" is identified as a rail, now extinct, and the strange seal-like creature from St. Helena is thought to be a sea elephant, which, although never recorded from so far north, is a very strong swimmer, and it is apparently just possible that one could have reached this island. The third picture represents a whale, identified by Mr. Fraser as an adult Atlantic right whale. Mundy's description of the feeding mechanism is stated to be quite correct, and he is probably one of the first to have given a true account of this.

\section{Zoological Gardens of Travancore}

IT is not easy to realise what great efforts are being made in all parts of the Empire for the interest and instruction of the people in matters of natural history. The Zoological Section of the Public Gardens at Trivandrum contained last year ("the year 1109 M.E.") 149 mammals, 225 birds, 26 reptiles and 20 fishes ; and the growing popularity of the institution was indicated by an increase in the number of visitors to 462,566 from the 302,425 of the preceding year. 
Extensive improvements were carried out, including the building of a new aviary, the extension of the carnivora house, and an open arena for lions and tigers. And "all the members of the menial staff of the three Sections were provided with suitable uniforms, for the first time, with suggestive badges for the respective groups; and the whole staff looks exceedingly smart when thus arrayed on ceremonial and festive occasions. . . The year 1109 was one of the most progressive in the annals of the institution, and has marked an important land mark in the various stages of its development for years." (Administration Report to the Government of His Highness the Maha Raja of Travancore, 1109 M.E.)

\section{Marine Biology in Ceylon}

THE administrative report for 1934 of the marine biologist of Ceylon, Mr. A. H. Malpas, shows that as the results of restricted inspections by dredging of the pearl banks there were no spatfalls in the northern paars and Cheval paars. A certain number of second and third year oysters were, however, present, but not in sufficient quantities to offer a prospect of immediate fisheries, although if conditions are favourable they may provide heavy spatfalls. A scheme has been prepared for the establishment in Colombo of a fisheries research station combined with an aquarium which is under consideration. This provides in the first instance for a small biological research station capable of being enlarged as funds are available. It will be equipped with research laboratories and freshwater and marine aquaria essential for fisheries investigation work. An aquarium will be attached, to which the public will be admitted. This is an alternative scheme to one outlined in earlier reports which provided for exhaustive investigations in these waters with a modern fishing vessel equipped with the latest fishing appliances in order to determine the lines on which the local industries could be most profitably developed, which the Executive Committee for Local Administration has definitely decided to abandon. Under the new scheme, the field of research will include investigations into life-histories and general bionomics of all aquatic animals of importance in Ceylon, into the culture of pearl and edible oysters, into the farming of estuaries and fresh-water fishes and turtle, and into the importance of various indigenous larvivorous fishes in relation to the suppression of tropical fevers and the breeding and distributing of the most active forms throughout Ceylon.

\section{Baltic Countries}

The Baltic Institute, which was founded at Torun in Poland in 1926 for the investigation of Polish and Pomeranian economic problems, has widened its scope in the publication of a journal entitled Baltic Countries, which is to appear three times a year at the annual cost of five dollars. The August number contains more than a dozen articles, all in English, on various aspects-geographical, economic and historical — of Sweden, Finland,Denmark, Estonia and other Baltic lands. Russia and Germany are excluded from the scope of the review. The editorial committee of twelve is drawn from the universities of Baltic and Scandinavian countries, England and the United States. A supplement to the issue contains the first instalment of the proposed Baltic Year Book which gives the usual statistical tables. This is to be completed in four issues, and then published separately. Baltic Countries promises to be a useful addition to geographical and economic journals.

\section{Religious Broadcasting at the Eucharistic Congress}

ThE broadcasting of the services at the International Eucharistic Congress of World Catholicism at Buenos Aires in October 1934 to the largest and most widely diffused religious congregation in history was made possible by the radio telephone. On the closing day, October 14, the Pope, Pius XI, speaking into a microphone on his desk at the Vatican, gave the concluding message not only to a million worshippers kneeling in the streets of the Argentine capital, but also, by means of retransmissions from Buenos Aires to broadcasting stations on three continents, to a very considerable proportion of the clergy and laity throughout the world. In Electrical Communication of July, two papers describe the broadcasting arrangements and the radio telephone system which rendered possible this world-wide service. No longer are the delegates to these international congresses crowded together in a cathedral with straining ears. Walls or park boundaries or national frontiers or even oceans now offer no restrictions. Without wireless, the management of the large crowds drawn from a metropolitan area having nearly three million inhabitants would have presented almost insuperable difficulties. Chile, Peru and Colombia were linked up by transcontinental land lines and Uruguay by a subfluvial cable. The able and willing co-operation of the Government telephone departments of many of the leading countries in the world ensured the success of the international broadcasts.

\section{Industrial Power in Great Britain}

A $x$ the National Electrical Convention held at Bournemouth on June 3-8, a paper on industrial power supply was read by F. Forrest, H. Hobson and C. Taite. They examine very thoroughly the dependence of Great Britain upon her manufacturing industries and how much mechanical and electrical power they take. Although widely extended use is being made by industry of the public electric supply services, a still wider use is advocated, as it has a cumulative effect upon economy of production, and many of the existing mechanical power plants are not economical. The introduction of labour-saving devices has proceeded more slowly in Great Britain than elsewhere; mass production methods also are much more widely applied in the United States and Germany. Compared with her principal competitors, there is a relative deficiency in the total power equipment per wage earner of Britain. This deficiency is partly due to the nature of British industries, which demand a greater proportion of hand processes, and 